\title{
Qualitative analysis of the risk of introducing Gyrodactylus salaris into the United Kingdom
}

\author{
E. J. Peeler*, M. A. Thrush \\ Centre for Environment, Fisheries and Aquaculture Science, Barrack Road, The Nothe, Weymouth DT4 8UB, UK
}

\begin{abstract}
Gyrodactylus salaris is a freshwater, monogenean ectoparasite of Baltic strains of Atlantic salmon Salmo salar on which it generally causes no clinical disease. Infection of other strains of Atlantic salmon in Norway has resulted in high levels of juvenile salmon mortality and highly significant reductions in the population. The parasite is a major exotic disease threat to wild Atlantic salmon in the UK. This paper qualitatively assesses the risk of introduction and establishment of $G$. salaris into the UK. The current UK fish health regime prevents the importation of live salmonids from freshwater in territories that have not substantiated freedom from G. salaris. The importation of other species, e.g. eels Anguilla anguilla and non-salmonid fish, represents a low risk because the likelihood of infection is very low and the parasite can only survive on these hosts for less than $50 \mathrm{~d}$. Importation of salmon carcasses presents a negligible risk because harvested fish originate from seawater sites and the parasite cannot survive full strength salinity. The importation of rainbow trout Oncorhynchus mykiss carcasses from G. salaris infected freshwater sites might introduce the parasite, but establishment is only likely if carcasses are processed on a salmonid farm in the UK. A number of mechanical transmission routes were considered (e.g. angling equipment, canoes, ballast water) and the most important was judged to be the movement of live fish transporters from farms on mainland Europe direct to UK fish farms. In the future, territories may have to substantiate freedom from G. salaris and economic drivers for live salmonid imports may strengthen. Under these circumstances, legal or illegal live salmonid imports would become the most significant risk of introduction.
\end{abstract}

KEY WORDS: Gyrodactylus salaris $\cdot$ Import risk analysis $\cdot$ Salmonid $\cdot$ Fish $\cdot$ Disease

\section{INTRODUCTION}

Gyrodactylus salaris is a viviparous, monogenean ectoparasite that infects Atlantic salmon Salmo salar in freshwater. Its original geographic range was the Baltic watershed where infection has not been associated with clinical disease or mortality (Malmberg \& Malmberg 1993). In contrast, introduction of the parasite to Norway resulted in serious disease and high levels of mortality in infected Atlantic salmon stocks. The high genetic susceptibility of Norwegian stocks to G. salaris, compared with Baltic stocks, has been demonstrated (Bakke et al. 1990b). However, recently published work has indicated that considerable variation in G. salaris resistance exists between Baltic stocks and some may be as susceptible as Norwegian Atlantic salmon (Bakke et al. 2004).
Gyrodactylus salaris was introduced into Norway, probably via salmon parr imported from Sweden in the early 1970s (Mo 1994) and has resulted in the collapse of wild salmon populations in 45 Norwegian rivers (T. A. Mo pers. comm.). Environmental factors, including water chemistry, appear to mediate the impact of the parasite on the salmon population (T. A. Mo pers. comm.). In Norway, elimination of the parasite has been achieved in 16 rivers by the chemical destruction of all fish life (a further 5 remain under surveillance following treatment). The parasite is listed by the Office International des Epizooties (OIE) in the Aquatic Animal Health Code (OIE 2003a). It is a notifiable disease in the UK (Fish Disease Act 1983), where it has never been recorded. Farmed salmonid fish are regularly inspected for $G$. salaris and ad hoc and routine surveys of wild fish have been undertaken. G. salaris is a seri- 
ous threat to the salmon population of the UK because it is highly likely that they are as susceptible as Norwegian stocks (Bakke \& MacKenzie 1992, MacKenzie 1993). In addition, the use of rotenone to eliminate $G$. salaris may be logistically impossible, due to the complex hydrography of many river systems, and environmentally unacceptable.

Only recently has risk analysis been applied in aquaculture (Rodgers 2001). One of its main animal health applications is the assessment of the likelihood and consequences of importing exotic pathogens. A formal risk analysis ensures a thorough and logical approach is adopted in considering the likelihood and consequences of undesirable events. The application of risk analysis can greatly improve the scientific underpinning of decision-making in the field of aquatic animal health.

We used qualitative risk analysis to assess the likelihood of Gyrodactylus salaris introduction given the current levels of protection (i.e. restricted risk analysis). There are 4 stages to a complete import risk analysis (OIE 2001, 2003a): (1) hazard identification, (2) risk assessment, (3) risk management and (4) risk communication. Communication with the relevant stakeholders of a risk analysis is an important component of the process and may be appropriate at any stage of the process (OIE 2003a). Risk assessment is further subdivided into: (1) release assessment (description of pathways necessary for introduction), (2) exposure assessment (description of pathways necessary for the exposure of aquatic species in the importing country to the introduced exotic pathogen), (3) consequence assessment (identification of the consequences of disease introduction and establishment) and (4) risk estimation (integration of the release, exposure and consequence assessments) (OIE 2003a).

In this paper, the geographical distribution of the parasite and its biophysical properties were used to identify and assess potential routes of spread. The release and exposure pathways were considered for

Table 1. Description of terms used to describe the risk (Kahn et al. 1999)

\begin{tabular}{|ll|}
\hline Risk & Description \\
\hline Very high & Almost certain to occur \\
High & Expected to occur \\
Moderate & Less than 50:50 probability \\
Low & Unlikely to occur \\
Very low & Rarely occur \\
Extremely low & Very rarely occur \\
Negligible & Chance of occurrence so small it can be \\
& ignored \\
\hline
\end{tabular}

each route of introduction of Gyrodactylus salaris into the UK. By definition, in a qualitative risk analysis, one is using terms or scoring to define the risk and consequences. The clarity of the results are improved if the terms used are defined and in this paper, definitions are based on those developed by Kahn et al. (1999) (Table 1). A preliminary assessment of the consequences of introduction was also made. The priorities for future quantitative analyses and other research are discussed.

\section{THE PARASITE HAZARD}

\section{Host range}

Gyrodactylus salaris reproduces and survives permanently only on Atlantic salmon and rainbow trout Oncorhynchus mykiss (Bakke et al. 1991) (infection causes no clinical signs in rainbow trout). However, the parasite can live for periods of 7 to $50 \mathrm{~d}$ on other salmonid and non-salmonid species, without causing clinical disease (Bakke et al. 1990a, 1992a,b, Bakke \& Sharp 1990, Jansen \& Bakke 1995, Soleng \& Bakke 2001) including eels Anguilla anguilla (maximum duration of infection 8 d) (Bakke \& Jansen 1991). The parasite survives longest ( 50 d) on brown trout Salmo trutta (Jansen \& Bakke 1995) and grayling Thymallus thymallus (Soleng \& Bakke 2001), on which limited reproduction is possible.

\section{Geographic distribution}

The original geographic distribution of Gyrodactylus salaris is the Baltic watershed (western Sweden, northern Finland and northern Russia). It has been introduced to Norway, Denmark (Buchmann \& Bresciani 1997, Nielsen \& Buchmann 2001) and Germany (Cunningham et al. 2003). Reports of G. salaris in France (Johnston et al. 1996) have been disputed and it is generally agreed that the parasite found was a different species, G. teuchis (Lautraite et al. 1999). Similarly, reports of G. salaris in Spain and Portugal (Johnston et al. 1996) may also have been due to misidentification. However, the parasite has probably been spread widely within Europe with the movement of live rainbow trout (Bakke \& Harris 1998) and is present in more countries than currently known (OIE 2003b). Surveys to substantiate freedom from $G$. salaris have only been conducted in the UK, Ireland, some river catchments in Finland and France (Lautraite et al. 1999). There are no published data on the prevalence of $G$. salaris in Swedish fish farms; however, in Finland, G. salaris was found in $39 \%$ of all salmon farms (Haenninen et al. 
1995). A survey of 5 freshwater rainbow trout farms in Denmark found G. salaris in 4 farms (Buchmann \& Bresciani 1997). A more recent survey found G. salaris in 7 of 11 Danish rainbow trout farms; however, only 15 fish were sampled from each farm (Nielsen \& Buchmann 2001).

\section{Biophysical properties}

The importance of different routes of introduction will largely be influenced by the biophysical properties of Gyrodactylus salaris. The parasite has a short, direct life-cycle, produces live young, is highly fecund (Jansen \& Bakke 1991, Harris et al. 1994) and a single individual can cause an epidemic. Although phylogenetically G. salaris is a macroparasite, its life cycle is similar to a micro parasite (e.g. a virus or bacteria). $G$. salaris rapidly detaches from a dead host and is highly efficient at finding a new host (Soleng et al. 1999a). It can survive for 6 to $7 \mathrm{~d}$ off the host in low water temperatures (Mo 1987). It cannot survive desiccation, freezing or elevated temperatures. G. salaris dies in full strength salinity (>33\%) within $20 \mathrm{~min}$, but at $5 \%$ the parasite continues to reproduce and increase in number (Soleng \& Bakke 1997). For salinities between 7.5 and $20 \%$, survival time declines from $38 \mathrm{~d}$ to $16 \mathrm{~h}$, respectively (at $6^{\circ} \mathrm{C}$ ) (Soleng \& Bakke 1997). G. salaris is killed by aluminium sulphate at $202 \mu \mathrm{g} 1^{-1}$ (Soleng et al. 1999b, Poleo et al. 2004) and most disinfectants (e.g. $0.5 \%$ Virkon $^{\circledR} \mathrm{S}$, Antec International, T. A. Mo pers. comm.).

\section{PATHWAYS AND EXPOSURE}

\section{Pathways of introduction and preventive measures}

The pathways of introduction fall into 3 main categories: importation of live fish and gametes, importation of eviscerated fish carcasses and mechanical transmission. All identified pathways are listed by the 3 main categories in Table 2. Importations of live fish, gametes or fish carcasses from countries where Gyrodactylus salaris is found are potential routes of introduction. Movement of inanimate materials that carry fresh or low-salinity water, which have recently been in contact with infected fish, and have been kept in cool conditions, may mechanically introduce G. salaris. Equipment that may contain water and may move rapidly between freshwater areas includes lorries moving live fish, canoes and angling tackle (especially keep nets).

Protective measures to prevent the introduction of Gyrodactylus salaris into the UK are summarised in Table 3. The key protective measures are controls on the import of live salmonids and salmonid eggs. A European Commission (EC) decision (2004/453/EC) recognises that the UK is free of $G$. salaris and the importation of live salmonids is only permitted from other regions that have also demonstrated freedom (currently Eire and 2 river catchments in Finland) and from seawater sites where salinity does not fall below $25 \%$. Salmonid eggs can be imported from farms outside of regions recognised as free of $G$. salaris provided they are disinfected (Commission Decision 2004/453/ EC). Other protective measures are based on recommendations and advice. The risk analysis described here is based on the current protective measures, i.e. it is a restricted risk analysis.

\section{Exposure pathways}

Under experimental conditions, Scottish Atlantic salmon were found to exhibit the same degree of susceptibility to Gyrodactylus salaris as Norwegian Atlantic salmon (MacKenzie 1993). The water temperature and other conditions in the UK are suitable for the survival of $G$. salaris. Its simple, viviparous life cycle favours colonisation (Guegan \& Kennedy 1993). It is highly fecund and a single viable parasite might initiate a disease outbreak (depending inter alia on host density).

Table 2. Pathways of Gyrodactylus salaris introduction

\begin{tabular}{|c|c|}
\hline Category & Pathway \\
\hline $\begin{array}{l}\text { Live fish and } \\
\text { gametes }\end{array}$ & $\begin{array}{l}\text { Importation of live salmonids }{ }^{\mathrm{a}} \\
\text { Importation of eels }{ }^{\mathrm{b}} \\
\text { Importation of non-salmonid fish } \\
\text { Importation of rainbow trout eggs }\end{array}$ \\
\hline Fish carcasses & $\begin{array}{l}\text { Fresh or chilled Atlantic salmon } \\
\text { from Norway/Finland/Sweden } \\
\text { Fresh or chilled rainbow trout from } \\
\text { freshwater production in mainland } \\
\text { Europe }\end{array}$ \\
\hline $\begin{array}{l}\text { Mechanical } \\
\text { transmission }\end{array}$ & $\begin{array}{l}\text { Lorries moving live fish } \\
\text { Ships' ballast water } \\
\text { Well-boats travelling from Norway } \\
\text { Freshwater tanks of leisure craft } \\
\text { Canoes and angling equipment } \\
\text { (especially keep nets) } \\
\text { Importation of lumber from Baltic } \\
\text { countries } \\
\text { Importation of aquatic plants from } \\
\text { Baltic countries }\end{array}$ \\
\hline \multicolumn{2}{|c|}{$\begin{array}{l}{ }^{\mathrm{a}} \text { Currently no live salmonids are imported into the UK } \\
\text { with the exception of Eire } \\
\text { b Currently all eel imports originate from closed recircula- } \\
\text { tion systems }\end{array}$} \\
\hline
\end{tabular}


Table 3. Measures to prevent the introduction of Gyrodactylus salaris into the UK. EC: European Commission; IMO: International Maritime Organisation

\begin{tabular}{|c|c|c|}
\hline Route & Measure & Legislation/Reference \\
\hline Importation of live salmonids & Restricted to G. salaris free approved zones & EC Decision (2004/453/EC) \\
\hline Importation of salmonids eggs & Disinfection & EC Decision (2004/453/EC) \\
\hline $\begin{array}{l}\text { Live fish/eggs containers } \\
\text { and residual water }\end{array}$ & Disinfection or disposal & Guidelines in import certificate \\
\hline Live fish transporters & $\begin{array}{l}\text { Cleaning and disinfection recommended } \\
\text { before re-entry to the UK }\end{array}$ & $\begin{array}{l}\text { Disinfection guidelines in the ISA code of } \\
\text { practice (Anonymous 2000a) }\end{array}$ \\
\hline Angling equipment & Disinfection recommended & G. salaris awareness leaflet \\
\hline Boat traffic & $\begin{array}{l}\text { Ballast water discharge } \\
\text { outside UK coastal water }\end{array}$ & $\begin{array}{l}\text { IMO discharge of ballast water recom- } \\
\text { mendations }\end{array}$ \\
\hline
\end{tabular}

Depending on the release pathway, Gyrodactylus salaris parasites may be introduced to the farmed or wild environment. Atlantic salmon or rainbow trout farms provide an environment where the parasite will quickly locate a host and easily establish. The parasite can only establish in rivers with Atlantic salmon or rainbow trout populations. Rainbow trout are not native to the UK but farm escapees have established small breeding populations in 19 river catchments in England and Wales (R. Evans pers. comm.) and 14 in Scotland (Anonymous 2003) (although spawning is generally sporadic). Of the 180 river catchments in England and Wales, and many river catchments in Scotland, 89 have wild Atlantic salmon populations. Secondly, the free-living parasite must locate a host of a susceptible species before it dies (which is considerably less probable for the wild compared with the farm environment), establish infection and spread to other hosts. The viability of the parasite on entering the aquatic environment and, therefore, the time available to find a susceptible host will depend on the route of introduction (e.g. duration and conditions of transit).

\section{Release, exposure and risk estimation}

An estimate of the risk of release, exposure and risk and exposure combined for each route is given in Table 4 .

\section{IMPORTATION OF LIVE FISH AND GAMETES}

\section{Release assessment}

Salmonids. Currently, live salmonids are not imported into the UK with the exception of limited trade with Eire. Additionally, no evidence of illegal importation of live salmonids into the UK exists. Salmonid eggs can be imported from farms irrespec- tive of their Gyrodactylus salaris status, provided they are disinfected (EC Decision 2004/453/EC). Salmonid eggs are transported under conditions conducive for the survival of G. salaris (Mo 1987). Atlantic salmon Salmo salar eggs are currently imported from Norway (hatcheries in Norway are free of G. salaris, T. A. Mo pers. comm.) and rainbow trout Oncorhynchus mykiss eggs are imported from Denmark (where rainbow trout farms are known to be infected with G. salaris). However, exported eggs are 'eyed' and thus, have been kept for at least $14 \mathrm{~d}$ after stripping and without contact with broodstock (the parasite cannot survive longer than $7 \mathrm{~d}$ off the host). Additionally, a risk of introduction from Denmark only exists if disinfection is not carried out. The Department for Environment, Food and Rural Affairs (Defra) recommends that eggs be disinfected on arrival before being taken into the hatchery in the UK, which will further reduce the risk of introduction. The risk of introduction is estimated as negligible.

Non-salmonid fish. In the past, live eels have been imported into the UK from France, Ireland, New Zealand, Spain and China. In recent years, all eel imports originate from closed recirculation systems in the Netherlands where environmental contact is minimal and, therefore, risk of infection is negligible. The risk of introduction depends on the Gyrodactylus salaris status of the country and farm of origin; currently, the risk is negligible. Non-salmonid fish, notably carp, are legally imported into the UK from a limited number of sites in mainland Europe, none of which hold salmonids. It is believed that large numbers of non-salmonid fish, notably carp Cyprinus carpio, are illegally imported from mainland Europe for recreational fisheries (E. B. Hudson pers. comm.). These fish might originate from sites where salmonids are held and thus, an extremely low likelihood of introduction exists (generally salmonid species will not be found in the same stillwaters as cyprinids). 


\section{Exposure assessment}

Salmonids. It is almost certain that Gyrodactylus salaris would establish if introduced via the importation of live infected rainbow trout or Atlantic salmon; thus, the exposure risk is very high. The risk of exposure of contaminated eggs is lower than infected salmonids, mainly because the parasites are freeliving, but is still moderate.

Non-salmonids. Live eels are transported into the UK in water filled containers. The water may be changed after arrival in the UK. Under EU regulations (EC Directive 91/67), water should be changed at an official water station where discharged water can be treated; however, no such facilities exist in the UK. Lorries carrying imported live eels might pump out water, in which the eels are transported, into a river or stream before taking up fresh water. Some parasites might detach from the eels and thus, be flushed out when the water is changed. Alternatively, some eels might escape. The disposal of wastewater from the processing of eels also presents a potential route for Gyrodactylus salaris into the aquatic environment; however, most parasites are not likely to be viable and the likelihood of contacting a susceptible host is low. Overall, the exposure risk of live eel importation is moderate.
Usually imported carp and other non-salmonids are released into a stillwater fishery (e.g. lake or reservoir). Any Gyrodactylus salaris parasites associated with the fish or the water in which they were transported will be directly released into the aquatic environment. The large majority of non-salmonid fisheries do not contain Atlantic salmon or rainbow trout and thus, the parasite will not be able to establish. However, the outflow from the fishery may enter a river with a susceptible salmonid population. The exposure risk is estimated as low.

\section{IMPORTATION OF EVISCERATED FISH CARCASSES}

\section{Release assessment}

Annual imports of eviscerated salmon and trout carcasses are summarised by exporting country in Table 5. Harvested salmon originate exclusively from seawater, in which Gyrodactylus salaris cannot survive (Soleng \& Bakke 1997). In addition, the parasite dies rapidly if not covered with water, often leaves the host soon after death and will not survive freezing or cooking. Significant volumes of fresh or chilled

Table 4. Estimation of risk of Gyrodactylus salaris release and exposure

\begin{tabular}{|c|c|c|c|}
\hline \multirow[t]{2}{*}{ Pathway } & \multirow{2}{*}{ Release } & - Risk estimation- & \multirow[b]{2}{*}{ Overall } \\
\hline & & Exposure & \\
\hline \multicolumn{4}{|l|}{ Live fish and gametes } \\
\hline Importation of live salmonids & Negligible & Very high & Negligible \\
\hline Importation of eels & Negligible & Moderate & Negligible \\
\hline Importation of non-salmonid fish & Extremely low & Low & Extremely low \\
\hline Importation of rainbow trout eggs & Negligible & Moderate & Negligible \\
\hline \multicolumn{4}{|l|}{ Fish carcasses } \\
\hline Fresh/chilled Atlantic salmon from Norway/Finland/Sweden & Negligible & Negligible & Negligible \\
\hline Fresh/chilled rainbow trout from European freshwater production & High & Negligible & Negligible \\
\hline $\begin{array}{l}\text { Fresh/chilled rainbow trout from European freshwater production } \\
\text { imported for on-farm processing in the UK }\end{array}$ & Very low-low & Moderate & Very low \\
\hline $\begin{array}{l}\text { Mechanical transmission } \\
\text { Lorries moving live salmonid fish travelling from mainland Europe } \\
\text { direct to a UK fish farm }\end{array}$ & Very low & Moderate & Very low \\
\hline Ships' ballast water & Extremely low & $\begin{array}{l}\text { Extremely low- } \\
\text { negligible }\end{array}$ & Negligible \\
\hline Well-boats travelling from Norway & Negligible & Negligible & Negligible \\
\hline Freshwater tanks of leisure craft & Extremely low & $\begin{array}{l}\text { Extremely low- } \\
\text { negligible }\end{array}$ & Negligible \\
\hline Canoes and angling equipment (especially keep nets) & Extremely low & Very low & Extremely low \\
\hline Importation of lumber from Baltic countries & Negligible & $\begin{array}{l}\text { Extremely low- } \\
\text { negligible }\end{array}$ & Negligible \\
\hline Importation of aquatic plants from Baltic countries & Negligible & $\begin{array}{l}\text { Extremely low- } \\
\text { negligible }\end{array}$ & Negligible \\
\hline
\end{tabular}


Table 5. Average annual imports of whole eviscerated Atlantic salmon and rainbow trout carcasses for 1995 to 2000 (metric tonnes). Source: HM Customs \& Excise

\begin{tabular}{|lrrrr|} 
& $\begin{array}{r}\text { Fresh or chilled } \\
\text { Salmon }\end{array}$ & \multicolumn{2}{c|}{ Trout } & Frozen \\
& & & & \\
\hline Belgium-Luxembourg & 4 & 0 & 2 & 11 \\
Canada & 11 & 0 & 91 & 0 \\
Chile & 11 & 0 & 97 & 28 \\
China & 3 & 0 & 97 & 0 \\
Denmark & 150 & 49 & 77 & 185 \\
Eire & 822 & 175 & 36 & 45 \\
Faroe Islands & 3421 & 11 & 8 & 1 \\
France & 47 & 104 & 12 & 75 \\
Japan & 0 & 0 & 18 & 2 \\
Germany & 70 & 1 & 242 & 2 \\
Iceland & 277 & 3 & 20 & 4 \\
Netherlands & 13 & 29 & 131 & 27 \\
New Zealand & 0 & 0 & 3 & 0 \\
Norway & 6102 & 23 & 41 & 1 \\
Portugal & 0 & 0 & 0 & 16 \\
S Korea & 0 & 0 & 3 & 0 \\
Spain & 10 & 3 & 1 & 204 \\
Sweden & 871 & 0 & 1 & 154 \\
Thailand & 0 & 0 & 3 & 4 \\
USA & 182 & 0 & 1057 & $<1$ \\
Total & 11994 & 398 & 1940 & 760 \\
& & & & \\
\hline
\end{tabular}

salmon have been imported from Sweden and Norway in recent years (Table 5) without a G. salaris outbreak, which further suggests that this route presents a negligible risk. The majority of fresh rainbow trout imports to the UK come from Denmark and France. G. salaris is present in freshwater rainbow trout production in Denmark and the situation in France is uncertain. On average, 49 metric tonnes of fresh or chilled rainbow trout were imported annually from Denmark into the UK between 1995 and 2000 (Table 5). In 2000, $80 \%$ of Danish rainbow trout production was in freshwater (Ariel et al. 2002); thus, it can be estimated that approximately 40 metric tonnes of imported rainbow trout per year were from freshwater farms, of which a high proportion was infected with G. salaris. Research from Denmark found that the prevalence of $G$. salaris declined with the size of the fish and no G. salaris parasites were found on fish greater than $15 \mathrm{~cm}$ in length (Buchmann \& Bresciani 1997), indicating that the prevalence in harvested fish is probably low. Because G. salaris rapidly detaches from a dead host, many parasites are likely to be removed during processing. Nevertheless, some parasites are likely to remain on carcasses following processing. The duration and conditions of transport from Denmark to the UK are likely to be reasonably conducive for survival (i.e. cool and damp). The risk of release through the importation of rainbow trout carcasses is estimated as high. The pathways for the introduction of G. salaris with the importation of rainbow trout carcasses are shown in Fig. 1.

\section{Exposure assessment}

Gyrodactylus salaris parasites on imported salmonid carcasses need to gain access to the aquatic environment and find a suitable host within 5 to $7 \mathrm{~d}$ (exposure pathways are illustrated in Fig. 1). Effluent and waste from fish processing plants might contain G. salaris parasites. At most sites, solid waste is processed further and effluent enters the mains drainage untreated, but the parasite is extremely unlikely to enter the aquatic environment in a viable state. Parasites on uncooked scraps, discarded through the usual refuse disposal system, will almost certainly die before entering the aquatic environment (via runoff, seepage or scavenging by piscivorous birds from a landfill site). Viable parasites may enter a river or stream through unconventional routes (picnickers' discard of uncooked scraps into a river or stream or used as bait). However, these routes account for only an extremely small volume of imported rainbow trout. A few processing plants are sited on rainbow trout farms and the importation of fish carcasses directly to these farms creates moderate risk of exposure of the introduced parasite to the farmed population (mechanical transmission from the processing plant) or wild salmonids (through effluent discharge). The exposure risk for all other imports of salmonids carcasses is negligible.

\section{MECHANICAL SPREAD}

\section{Release assessment}

Live fish transporters. A number of live fish hauliers use the same vehicles in mainland Europe and the UK. One of these vehicles, travelling from an infected farm in Europe, could introduce Gyrodactylus salaris to the UK, if appropriate cleaning and disinfection procedures were not followed. Pools of water within the vehicle may allow G. salaris to survive the journey back to the UK. The risk of introduction will be particularly high if live, dead or dying fish accidentally remained in the vehicle. However, the number of journeys is likely to be few; thus, the likelihood of introduction can be estimated as very low.

Canoes and angling equipment. Gyrodactylids are not free swimming and prefer to be in contact with a substrate and hence may attach to equipment. The risk presented by canoes and angling equipment (e.g. which have been in direct contact with infected fish) is extremely low because the volume of water trans- 


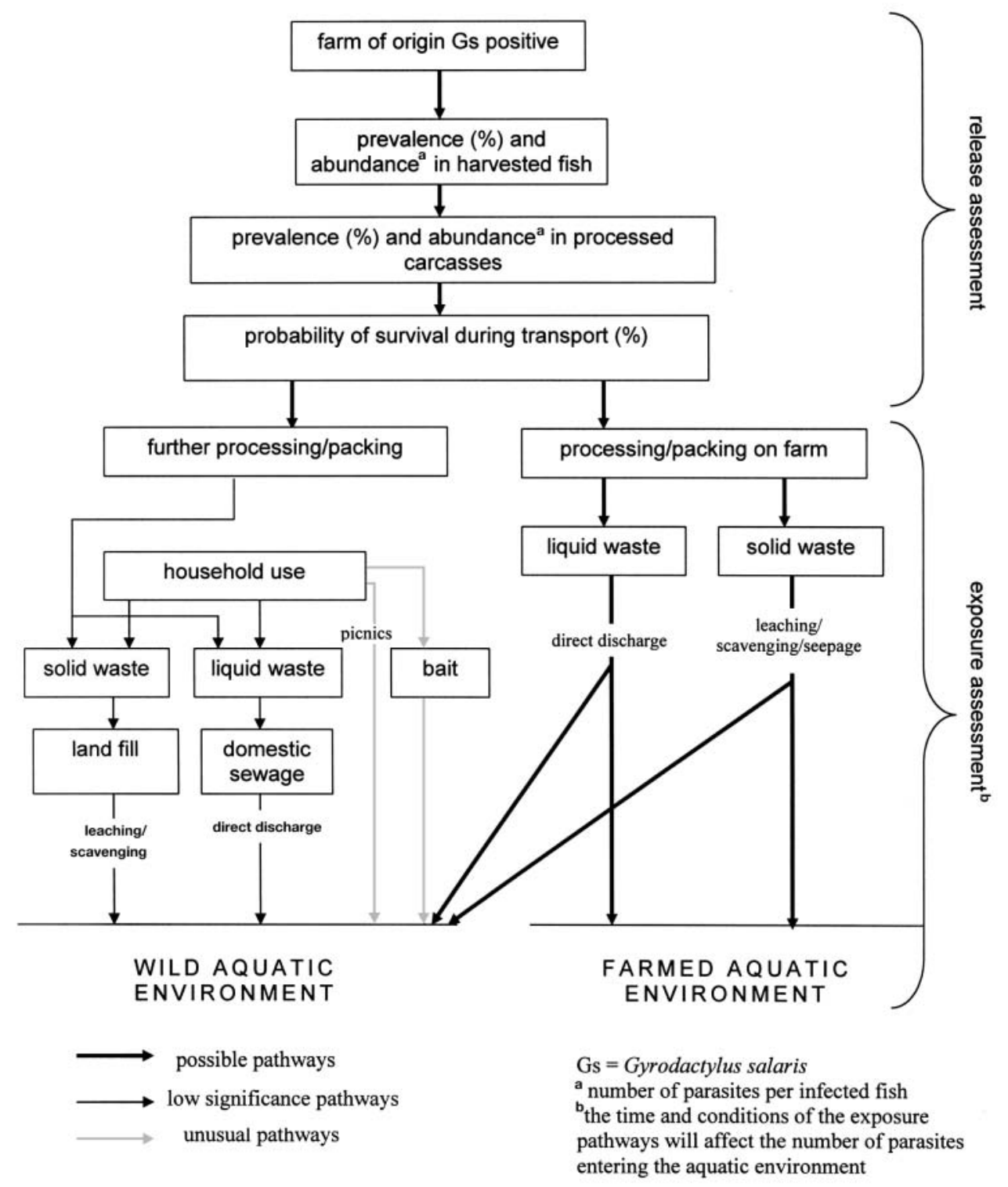

Fig. 1. Release and exposure pathways for the introduction of Gyrodactylus salaris via the importation of rainbow trout carcasses

ported is minimal (therefore, unlikely to contain a parasite) and the parasite is likely to be desiccated during transit. Canoes, boats, angling equipment etc., have not been implicated in the transmission of the parasite between rivers in Norway (T. A. Mo pers. comm.). This provides further evidence that these routes will not be significant for transmission over much longer distances (i.e. from mainland Europe to the UK).

Leisure craft, well-boats and ballast water. Small leisure craft sail between the UK and Scandinavia. These vessels contain freshwater tanks that may be replenished at remote anchorages when cruising in Scandinavia and very occasionally may be emptied in UK rivers or estuaries on their return. The risk pre- sented by this route is estimated as extremely low. Ballast water taken on by a boat from an estuary of a Gyrodactylus salaris infected river presents a higher risk due to the high volume of water. Discharge of the ballast water in an estuary in the UK, in contravention of current recommendations, would introduce the parasite; the risk of introduction is estimated as extremely low. Well-boats are used to transport Atlantic salmon including smolts. A few operators work in both Norway and Scotland, and some boats travel from Norway to seawater salmon sites in Scotland. Well-boats that have carried G. salaris infected salmon before travelling to the UK could introduce the parasite. However, the parasite has been eliminated from Norwegian 
hatcheries (T. A. Mo pers. comm.) and smolts are transported in seawater; thus, the risk is negligible.

Aquatic plants and lumber imports. The importation of aquatic plants and lumber from infected countries are potential routes of introduction; however, the risk posed by these routes can be considered as negligible because contact with potentially infected fish is almost non-existent.

\section{Exposure assessment}

Live fish transporters. Lorries used to carry live fish on mainland Europe, which on arrival in the UK travel directly to a fish farm with susceptible stocks creates a moderate risk of exposure since viable parasites might quickly gain access to a susceptible host.

Canoes and angling equipment. Gyrodactylus salaris parasites introduced to the UK attached to canoes or angling equipment are highly likely to become desiccated, or die because they are too long off a host, before reintroduction into the aquatic environment in the UK. The exposure risk is estimated as very low.

Leisure craft, well-boats and ballast water. Gyrodactylus salaris contaminated water in the freshwater tanks of leisure boats, or in ballast water of well boats, might be discharged into an estuary or river in the UK whilst the parasite is still viable. The likelihood of establishment is likely to be extremely low to negligible because the parasite will have been off a host for a considerable time before introduction; thus, the time available to find a host will be short and the density of the host population will, in general, be sparse. Introduction into an estuary will further reduce the likelihood of establishment since the salinity level will also limit the likely survival time. Similarly, the likelihood of establishment of $G$. salaris introduced by well-boats is negligible owing to the salinity level at seawater farm sites.

Aquatic plants and lumber imports. The risk of exposure is extremely low to negligible because the likelihood of contact between the introduced parasite and a susceptible host is remote.

\section{CONSEQUENCE ASSESSMENT}

Gyrodactylus salaris results in high levels of infection and mortality in juvenile Atlantic salmon. The wild Atlantic salmon population in affected Norwegian rivers was reported to be reduced by $98 \%$ in $5 \mathrm{yr}$ (Johnsen \& Jensen 1991). The parasite persists even when the host population has been greatly reduced. In the UK, recreational salmon fishing is an important source of revenue for many rural communities. The vir- tual elimination of salmon from an affected river inevitably will have severe localised socio-economic consequences. The flow-on ecological consequences are difficult to assess, but could be considerable. Nationwide, the impact of an outbreak will depend on the number of rivers affected, which in turn will depend largely on the time taken to detect the pathogen and the location of the index case. The presence of the pathogen is likely to go undetected for a considerable time in both farmed rainbow trout (on which it causes no clinical disease) and wild Atlantic salmon populations (where the first sign might be a population decline). It is, therefore, possible that many important salmon rivers will be affected before the parasite is discovered. The only proven method of control of G. salaris is elimination of all fish from a river using rotenone. This method is unlikely to be either successful or acceptable in the majority of river catchments. There are no published data on the impact of $G$. salaris on farmed salmon but control in freshwater facilities is straightforward (formalin baths). Infection in farmed trout is very unlikely to affect production. In the event of an outbreak, the movement of live trout from affected river catchments is likely to be severely curtailed because this is the most important route of spread (Peeler et al. 2004). Farms selling live trout for on-growing or restocking will be seriously affected. Following a G. salaris outbreak, monitoring and control programmes (to minimise the risk of spread) will continue indefinitely. The long-term ecological and financial consequences to both government and industry are potentially severe.

\section{DISCUSSION}

A qualitative risk analysis is a necessary first step to assess the potential pathways of disease introduction for an exotic pathogen based on the available information (Vose 2001). In this study, a qualitative approach effectively identified the movement of live fish transporters and the importation of rainbow trout carcasses for on-farm processing as, currently, the most significant pathways of introduction. Uncertainty exists around the estimates of risk mainly because of a lack of data regarding the volume of trade associated with most routes (e.g. amount of imported rainbow trout being processed on farms) and the number of parasites introduced per unit volume (e.g. per $\mathrm{kg}$ of imported rainbow trout). The identification of missing data is an important output of a risk analysis. A initial qualitative analysis allows limited resources to be focused on gathering or estimating, through expert opinion, information needed for more detailed, quantitative assessments of the main risks (Vose 2001). 


\section{Acceptable level of protection}

A zero-risk attitude to the risk of disease introduction, i.e. a precautionary approach, is not acceptable under the Sanitary and Phytosanitary (SPS) agreement of the World Trade Organisation (WTO). The acceptable level of risk should be based on the likely consequences of introduction, which in the case of Gyrodactylus salaris are potentially severe, but it is ultimately a political decision (Pharo 2003). The acceptable level of protection can be considered as the measures necessary to reduce the assessed level of risk to an acceptable level (Pharo 2003).

\section{Live fish imports}

Live salmonid imports inevitably present the most serious potential threat of introduction because the parasite will survive transport and the fish will be introduced into a farmed aquatic environment where the parasite can quickly establish. The international spread of fish diseases has most often been through the movement of live fish. The measures currently in place to restrict the importation of live salmonids undoubtedly reduce the level of risk significantly (live salmonids are only currently imported from Ireland, a Gyrodactylus salaris free country). In future, the level of risk might change with the volume and pattern of live fish imports. The importation of live salmonids from European countries or zones of equivalent health status is the most important potential future route of introduction. Depending on the surveillance and biosecurity systems in place, it is possible that G. salaris could be introduced into zones approved as G. salaris free and not be detected for a considerable time. This is a particular danger for zones with no significant Atlantic salmon populations (i.e. most of mainland Europe). A high level of targeted active surveillance would be required to ensure that the risk of $G$. salaris introduction via these imports was reduced to an acceptable level.

Currently, the risk from eel importations is negligible because they originate from closed recirculation systems; however, the situation may change. Similarly, the risk associated with non-salmonid fish imports would need to be re-evaluated if, in future, they originated from sites with salmonid species.

\section{Importation of fish carcasses}

There are few well-validated examples of the importation of eviscerated carcasses for human consumption resulting in the introduction of exotic fish pathogens. A number of risk analyses (LaPatra et al. 2001, Stone et al. 2001, MacDiarmid 1994) have shown that this route is of low risk; in general, because both the quantity of pathogen introduced is generally low and the likelihood of entering the aquatic environment is extremely low or negligible. Undoubtedly, fresh rainbow trout carcasses from infected farms might introduce small numbers of parasites into the UK. However, the only important exposure pathway is on-farm processing and packaging of imported carcasses. Obviously, this pathway presents a likelihood of introduction not only for Gyrodactylus salaris but also other diseases and requires further investigation. The risk of G. salaris introduction with eviscerated salmon carcasses is negligible because they originate from seawater. The importance of the salinity of seawater in determining the likelihood of G. salaris infection was highlighted in a quantitative risk analysis (Paisley et al. 1999).

\section{Live fish transporters}

For England and Wales, live fish transporters moving between mainland Europe and the UK probably presents the most serious threat of mechanical transmission, and merits further investigation. The role of live animal transporters in spreading diseases has been noted elsewhere. Empty eel transporters from mainland Europe coming to the UK to collect elvers (juvenile eels) are thought to have resulted in the introduction of the swim-bladder parasite of eels Anguillicola crassus to Great Britain (Kennedy 1990, Kennedy \& Fitch 1990). Empty animal transports returning to Denmark after delivering pigs to Germany have been identified as a potential route of introduction of classical swine fever into Denmark (Horst et al. 1999). Wellboats (used to carry live fish) might have introduced infectious salmon anaemia (ISA) to Scotland from Norway (Anonymous 2000b).

\section{Consequence assessment}

Three diseases have caused significant mortalities in wild European Atlantic salmon, namely furunculosis, ulcerative dermal necrosis (UDN) and Gyrodactylus salaris infection. Outbreaks of furunculosis (Bakke \& Harris 1998) and UDN (Roberts 1993) have been selflimiting and salmon stocks recovered. In contrast, $G$. salaris is highly likely to permanently reduce wild, susceptible Atlantic salmon populations in infected rivers to very low levels. The impact of $G$. salaris introduction into the UK will depend on the extent of its spread prior to detection and control. An assessment of the likely spread of the parasite through the movement of live salmonids is needed for a more complete conse- 
quence assessment and to underpin the development of contingency plans. The only proven method of eliminating G. salaris from a river is the destruction of all aquatic life (e.g. by use of rotenone), which has been adopted by Norway with some success. The long-term ecological damage of this programme has not been assessed (Bakke \& Harris 1998). The complex structure and large size of many river catchments in the UK might preclude the use of rotenone; additionally, it is unlikely to be environmentally acceptable. Therefore, it may only be possible to pursue a policy of containment, not eradication. The impact of G. salaris on salmon farming, recreational fishing and costs to government of control and monitoring can be calculated by standard economic methods; however, the ecological impact and the cultural loss of an iconic species, such as the Atlantic salmon, cannot be as easily assessed.

\section{Further research}

This study identified the importation of rainbow trout carcasses for on-farm processing and the movement of live fish transporters from Europe to the UK as potentially significant routes requiring further investigation. Ideally, these routes should be quantitatively evaluated to provide the best assessment on which to base a case for further measures (e.g. restriction of imports of salmonid carcasses for on-farm processing and mandatory disinfection of live fish transporters). Quantitative analysis requires data on the volume of rainbow trout imported for on-farm processing and the frequency of movement live fish transporters. Knowledge of the geographic distribution of Gyrodactylus salaris in Europe is also critical but largely unknown, partly because of the lack of robust, sensitive diagnostic tests and the reliance on expert judgement.

\section{CONCLUSION}

The opportunities for control and eradication of Gyrodactylus salaris are limited and the potential consequences of its introduction and establishment are devastating. It is therefore crucial that the potential pathways for introduction are assessed to ensure that the measures are in place that reduce the risk to introduction and establishment to an acceptable level. This study has identified current routes of entry that require further investigation (importation of rainbow trout carcasses for on-farm processing and the movement of live fish transporters) and potential risks that will depend on future patterns of trade (most importantly the importation of live salmonids).
Acknowledgements. The contributions of B. J. Hill and other colleagues at CEFAS, Weymouth, to this paper are gratefully acknowledged. P. Shave and C. Cunningham commented on early drafts of the paper. We thank T. A. Mo for his valuable assistance. This work was funded by Defra (contract F1150).

\section{LITERATURE CITED}

Anonymous (2000a) A code of practice to avoid and minimise the impact of infectious salmon anaemia. Joint government/Industry Working Group on ISA. Scottish Executive, Edinburgh

Anonymous (2000b) Final report of the the Joint Government/ Industry Working Group on Infectious Salmon Anaemia (ISA) in Scotland. Scottish Executive, Edinburgh, p 135

Anonymous (2003) Status of rainbow trout in Scotland: the results of a questionnaire survey. Fisheries Research Institute, Aberdeen, p 32

Ariel E, Mortensen HF, Olesen NJ (eds) (2002) Report of the fifth annual meeting of the EU national reference laboratories for fish diseases. Brussels, 13-14 November 2001. The community reference laboratory for fish diseases, Aarhus

Bakke TA, Harris PD (1998) Diseases and parasites in wild Atlantic salmon (Salmo salar) populations. Can J Fish Aquat Sci 55:247-266

Bakke TA, Jansen PA (1991) Experimental transmission of Gyrodactylus salaris Malmberg, 1957 (Platyhelminthes, Monogenea) from the Atlantic salmon (Salmo salar) to the European eel (Anguilla anguilla). Can J Zool 69:733-737

Bakke TA, MacKenzie K (1992) Comparative susceptibility of native Scottish and Norwegian stocks of Atlantic salmon, Salmo salar L., to Gyrodactylus salaris Malmberg: laboratory experiments. Int Counc Explor Sea (ICES), Copenhagen

Bakke TA, Sharp LA (1990) Susceptibility and resistance of minnows, Phoxinus phoxinus (L.) to Gyrodactylus salaris Malmberg, 1957 (Monogenea) under laboratory conditions. Fauna Norv Ser A 11:51-55

Bakke TA, Jansen PA, Brabrand A (1990a) Susceptibility and resistance of brook lamprey, Lampetra planeri (Bloch), roach, Rutilus rutilus (L.) and perch, Perca fluviatilis L. to Gyrodactylus salaris Malmberg (Monogenea). Fauna Norv Ser A 11:23-26

Bakke TA, Jansen PA, Hansen LP (1990b) Differences in the host resistance of Atlantic salmon, Salmo salar L., stocks to the monogenean Gyrodactylus salaris Malmberg, 1957. J Fish Biol 37:577-587

Bakke TA, Jansen PA, Kennedy CR (1991) The host specificity of Gyrodactylus salaris Malmberg (Platyhelminthes, Monogenea): Susceptibility of Oncorhynchus mykiss (Walbaum) under experimental conditions. J Fish Biol 39: 45-57

Bakke TA, Harris PD, Jansen PA (1992a) The susceptibility of Salvelinus fontinalis (Mitchill) to Gyrodactylus salaris Malmberg (Platyhelminthes; Monogenea) under experimental conditions. J Fish Biol 41:499-507

Bakke TA, Jansen PA, Grande M (1992b) The susceptibility of Salvelinus namaycush (Walbaum) to Gyrodactylus salaris Malmberg (Platyhelminthes; Monogenea) under experimental conditions. Fauna Norv Ser A 13:1-7

Bakke TA, Harris PD, Hansen H, Cable J, Hansen LP (2004) Susceptibility of Baltic and East Atlantic salmon stocks Salmo salar stocks to Gyrodactylus salaris (Monogenea). Dis Aquat Org 58:171-178

Buchmann K, Bresciani J (1997) Parasitic infections in pond- 
reared rainbow trout Oncorhynchus mykiss in Denmark. Dis Aquat Org 28:125-138

Cunningham CO, Collins CM, Malmberg G, Mo TA (2003) Analysis of ribosomal RNA intergenic spacer (IGS) sequences in species and populations of Gyrodactylus (Platyhelminthes: Monogenea) from salmonid fish in Northern Europe. Dis Aquat Org 57:237-246

Guegan JF, Kennedy CR (1993) Maximum local helminth parasite community richness in British freshwater fish: A test of the colonization time hypothesis. Parasitology 106:91-100

Haenninen ML, Ridell J, Hirvelae-Koski V (1995) Phenotypic and molecular characteristics of Aeromonas salmonicida subsp. salmonicida isolated in southern and northern Finland. J Appl Bacteriol 79:12-21

Harris PD, Jansen PA, Bakke TA (1994) The population age structure and reproductive biology of Gyrodactylus salaris Malmberg (Monogenea). Parasitology 108:167-174

Horst HS, Dijhuizen AA, Huirne RBM, Meuwissen MPM (1999) Monte Carlo simulation of virus introduction into the Netherlands. Prev Vet Med 41:209-229

Jansen PA, Bakke TA (1991) Temperature-dependent reproduction and survival of Gyrodactylus salaris Malmberg, 1957 (Platyhelminthes: Monogenea) on Atlantic salmon (Salmo salar L.). Parasitology 102:105-112

Jansen PA, Bakke TA (1995) Susceptibility of brown trout to Gyrodactylus salaris (Monogenea) under experimental conditions. J Fish Biol 46:415-422

Johnsen BO, Jensen AJ (1991) The Gyrodactylus story in Norway. Aquaculture 98:289-302

Johnston C, Mackenzie K, Cunningham CO, Eiras JC, Bruno DW (1996) Occurrence of G. salaris, Malmberg 1957, in Portugal. Bull Eur Assoc Fish Pathol 16:89-91

Kahn SA, Beers PT, Findlay VL, Peebles IR, Durham PJ, Wilson DW, Gerrity SE (1999) Import risk analysis on nonviable salmonids and non-salmonids marine finfish. Australian Quarantine and Inspection Service, Canberra

Kennedy CR (1990) Helminth communities in freshwater fish: Structured communities or stochastic assemblages? In: Esch G, Bush A, Aho J (eds) Parasite communities: patterns and processes. Chapman \& Hall, New York, p 131-156

Kennedy CR, Fitch DJ (1990) Colonization, larval survival and epidemiology of the nematode Anguillicola crassus, parasitic in the eel, Anguilla anguilla, in Britain. J Fish Biol 36: $117-131$

LaPatra SE, Batts WN, Overturf $\mathrm{K}$, Jones GR, Shewmaker WD, Winton JR (2001) Negligible risk associated with the movement of processed rainbow trout, Oncorhynchus mykiss (Walbaum), from an infectious haematopoietic necrosis virus (IHNV) endemic area. J Fish Dis 24:399-408

Lautraite A, Blanc G, Thiery R, Daniel P, Vigneulle M (1999) Gyrodactylids parasitizing salmonids in Brittany and Western Pyrenees water basins: Epidemiological features of infection and species composition. Bull Fr Peche Piscic 355:305-325

MacDiarmid SC (1994) The risk of introducing exotic diseases of fish into New Zealand through the importation of ocean caught pacific salmon from Canada. Ministry of Agriculture and Forestry Regulatory Authorities, Wellington

MacKenzie K (1993) Susceptibility of native Scottish stocks of salmon to Gyrodactylus salaris. In: Pirquet KT (ed) The 10th Annual Meeting of the Aquaculture Association of Canada, Charlottetown. Aquaculture ssociation of Can-

Editorial responsibility: Chris Baldock,

Brisbane, Australia ada, St. Andrews, p 105-107

Malmberg G, Malmberg M (1993) Species of Gyrodactylus (Platyhelminthes, Monogena) on salmonids in Sweden. Fish Res 17:59-68

Mo TA (1987) Taksonomiske og biologiske undersokeler, virksomheten i 1986 og forslag til virksomhet i 1987. University of Oslo

Mo TA (1994) Status of Gyrodactylus salaris problems and research in Norway, In: Lewis JW (ed) Parasitic diseases of fish. Samara Publishing, Dyfed, p 43-48

Nielsen CV, Buchmann K (2001) Occurrence of Gyrodactylus parasites in Danish fish farms. Bull Eur Assoc Fish Pathol 21:19-25

OIE (2003a) International aquatic animal health code - fish, molluscs and crustaceans, 6th edn. Office International des Epizooties, Paris

OIE (2003b) International manual of diagnostic tests for aquatic animals, 4th edn. Office International des Epizooties, Paris

Paisley LG, Karlsen E, Jarp J, Mo TA (1999) A Monte Carlo simulation model for assessing the risk of introduction of Gyrodactylus salaris to the Tana river, Norway. Dis Aquat Org 37:145-152

Peeler EJ, Gardiner R, Thrush MA (2004) Qualitative risk assessment of routes of transmission of the exotic fish parasite Gyrodactylus salaris between river catchments in England and Wales. Prev Vet Med 64:175-189

Pharo HJ (2003) The limits to quantification in import risk analysis. In: Hurd D, Salman M, Hernandez J (eds) 10th International Symposium for Veterinary Epidemiology and Economics, Vina del Mar, November 17-21, 2003. International Society for Veterinary Epidemiology and Economics, Santiago

Poleo ABS, Schjolden J, Hansens H, Bakke TA Mo TA (2004) The effect of various metals on Gyrodactylus salaris (Platyhelminthes, Monogenea) infections in Atlantic salmon (Salmo salar). Parasitology 128:1-9

Roberts RJ (1993) Ulcerative dermal necrosis (UDN) in wild salmonids. Fish Res 17:3-14

Soleng A, Bakke TA (1997) Salinity tolerance of Gyrodactylus salaris (Platyhelminthes, Monogenea): laboratory studies. Can J Fish Aquat Sci 54:1837-1845

Soleng A, Bakke TA (2001) The susceptibility of grayling (Thymallus thymallus) to experimental infections with the monogenean Gyrodactylus salaris. Int J Parasitol 31: 793-797

Soleng A, Jansen PA, Bakke TA (1999a) Transmission of the monogenean Gyrodactylus salaris. Folia Parasitol 46: 179-184

Soleng A, Poleo ABS, Alstad NEW, Bakke TA (1999b) Aqueous aluminium eliminates Gyrodactylus salaris (Platyhelminthes, Monogenea) infections in Atlantic salmon. Parasitology 119:19-26

Stone MAB, MacDiarmid SC, Pharo HJ (2001) Import Health Risk Analysis: Salmonids for human consumption. In: Rodger CJ (ed) Risk analysis in aquatic animal health. Proc OIE Int Conf, Paris, 8-10 February 2000. Office International des Epizooties (OIE), Paris, p 230-239

Vose D (2001) Qualitative versus quantitative risk analysis and modelling. In: Rodger CJ (ed) Risk analysis in aquatic animal health. Proc OIE Int Conf, 8-10 February, 2000. Office International des Epizooties (OIE), Paris, p 19-26

Submitted: March 22, 2004; Accepted: July 9, 2004

Proofs received from author(s): October 15, 2004 